\title{
Introduction
}

\section{Epistemic Circle and History of the Armenian Genocide}

This book sheds light on seemingly paradoxical times. Heads of state increasingly apologize for atrocities committed by their countries, and humankind builds institutions to prevent, or to respond to, mass violence. Some even speak of a justice cascade. Yet mass violence, silencing, and the denial of genocides continue. We also live in an era in which populist leaders deny what overwhelming evidence documents. They tell their followers, for example, that "global warming" is a hoax, even a Chinese conspiracy, advanced to damage the American economy. In countries as diverse as the United States, the Philippines, Brazil, China, and Russia, they present themselves as saviors and spew falsehoods, "alternative facts," that fly in the face of solid scholarly evidence.

Closer to the theme of this book is denial of repression, mass atrocity, and genocide. We encounter this denial, against overwhelming evidence, in places such as Burma (Myanmar) with regard to the Rohingya; in Sudan with regard to the Fur, the Masalit, and the Zaghawa; in China with regard to the Uighurs; and in Turkey, where, despite great historical distance, political leaders continue to deny the genocide against the Ottoman Armenians committed during World War I. Populist political leaders are not alone in their denial. The populace often follows suit and at times encourages politicians' denialist practices. At times, silencing takes the place of denial. The long American history of silencing the near extinction of the American Indian population is but one example. The silencing of the Holocaust in this author's native Germany during the 1950 and 1960 os is another. Even victim groups often silence the violence they experienced, albeit for different reasons, and this book speaks to that too.

In this contradictory and puzzling context, I ask how we know about genocide. Why do various collectivities and their leaders deny, silence, or recognize the same event of mass violence differently? Why do some insist on defining events 
as genocide, while others forcefully reject the label? This book is specifically about the emergence of radically distinct repertoires of knowledge about the Armenian genocide, which moved from broad acknowledgment to denial among Turks and from silencing to determined recognition among Armenians. The time span of more than a century during which this drama played out allows for insights into historical shifts and their drivers that the study of a more recent event would not grant.

This introduction summarizes themes, central theoretical ideas, and the chapters organized along those ideas. It speaks to empirical evidence, the data I use to illustrate and examine the validity of theoretical ideas. It specifies for whom I wrote this book, and it finally offers a brief historical overview of the Armenian genocide.

\section{KNOWLEDGE ABOUT GENOCIDE-THE SUBJECT OF THIS BOOK}

As I engage with the sociology of knowledge, I draw on and contribute to classical and contemporary strands of this sociological perspective. I show that each of them also applies to knowledge about genocide. Throughout this book, knowledge does not mean certified knowledge. Instead, as noted in the preface, the term simply refers to that which humans take for granted, to the perceived "certainty that phenomena are real and that they possess specific characteristics" (Berger and Luckmann 1966: 1). Repertoires of knowledge are clusters of such certainties that pertain to a particular set of phenomena, for example historical events.

Interactionist traditions in sociology show how humans produce an understanding of social reality (knowledge) in their daily interactions, communications, and thought processes. The literature, biographies, diaries, interviews, and observations of those who were touched by mass violence-as victims, as perpetrators, or as their descendants-serve as data. They document the unfolding of silencing, denying, or acknowledging when members of families, neighbors, friends, or humanitarians address (or avoid) the topic of genocide, as chapter 1 shows. Inner conversations supplement social interactions. They unfold, in George Herbert Mead's terms, between the I and the Me, the part of the self that assumes patterns of attitudes among others. Going beyond Mead, I see these patterns as embedded in social fields. ${ }^{1}$ Such inner conversations become visible in correspondence and diaries kept by humanitarians and other observers, which I examine in chapter 2.

Peter Berger and Thomas Luckmann, in The Social Construction of Reality, show how knowledge constructed through self-reflection and millions of interactive situations becomes sedimented. It solidifies into knowledge repertoires of collectivities, "carrier groups" in the words of Max Weber and Karl Mannheim. Yet, where Berger and Luckmann suggest harmony, we may in fact find disagreement and-importantly-diametrically opposed sets of knowledge across social groups. 
Such an outcome becomes visible in debates about mass atrocities, includingwith particular intensity - the Armenian genocide.

We also see that not all actors have equal chances to contribute to the construction of knowledge, a point overlooked by Berger and Luckmann. Asymmetries in power and communicative capacities affect outcomes. Knowledge entrepreneurs, acting from privileged institutional positions, shape and spread their group's definition of social reality to wider audiences. They also seek to manipulate, intensify, mobilize, or alter knowledge repertoires of carrier groups with which they are associated. Constructionist social problems theory, and scholars of reputations such as Barry Schwartz and Gary Fine, highlight the role of entrepreneurs in the construction of knowledge, in instilling in larger publics a specific definition of reality. These insights also apply, as Jeffrey Alexander has shown, to the role of entrepreneurs in the processing of horrendous experiences that threaten the existence or self-understanding of a collectivity, in the generation of cultural trauma after genocide. Finally, knowledge is not as stable as Berger and Luckmann suggest. It is at times dormant. Entrepreneurs may mobilize and alter it. In chapter 3, I deposit these theoretical concepts and ideas in a toolbox from which I draw in subsequent chapters.

The process of sedimentation of knowledge about the Armenian genocide among Armenians, in their own country and in the diaspora, is the subject of chapter 4 . Chapter 5 examines the evolution and sedimentation of Turkish knowledge. Throughout these chapters, I draw from literature that provides analyses of memoirs, banners displayed at demonstrations, memorial sites, news media, and textbooks.

Where different collectivities generate radically distinct repertoires of knowledge, their encounter with "the other" becomes a challenge they need to address. One option is the enactment of public rituals through which each group seeks to protect and reinforce its identity and knowledge. Armenian genocide commemorations, across the diaspora and centrally in Yerevan, Armenia's capital city, held on each April 24, provide an excellent example. The Turkish state instead has developed rituals to cleanse the memory of the Ottoman Empire and to celebrate unambiguously its history, disregarding its dark sides. Émile Durkheim and a new school of neo-Durkheimian thought explores the role of rituals in public life: their capacity to evoke a sense of group integration and collective effervescence and to solidify shared beliefs. This literature provides us with valuable tools for the analysis of Armenian and Turkish rituals, the focus of chapter 6. Ethnographic observation is the key method here.

Yet collectivities and their leaders do not just seek to solidify knowledge repertoires within their own groups. They also openly attack those of "the other" in conflictual processes. The Turkish state has attempted, with growing intensity, to challenge knowledge about the Armenian genocide. Armenians have fought, in return, for the recognition of their history. The form such conflicts take, and their 
outcomes, vary by social fields in which actors carry them out (politics and law, for example). Each field follows, in the terms of Pierre Bourdieu, its own rules of the game. Yet players in these fields also enjoy discretion. They improvise, with at times unpredictable outcomes. They finally act within institutions that differ across countries, while also being connected to world society.

Politics is a central social field in which conflicts over knowledge unfold. In chapter 7 , I explore political struggles over knowledge pertaining to the Armenian genocide in France, using interviews and document analysis as key methods. The French case is most relevant, because the country is home to the largest Armenian diaspora per capita and because conflicts over historical knowledge feature prominently in French politics. At stake are "memory laws" promulgated by legislative bodies. They reach from simple statements of acknowledgment to laws that criminalize denialist utterances. Many countries have recognized the Armenian genocide over the past two decades, often through legislative votes. Examining the French case under a microscope sheds light on the specific struggles and mechanisms of power at work.

The legal field is another battleground. Past research has focused on the contributions to knowledge and memory of trials against perpetrators of mass violence. Chapter 8, cowritten with Brooke B. Chambers, deals with a different type of legal engagement, formally a fight over free speech rights. We examine an American court case, Griswold v. Driscoll, in which Turkish interest groups mobilized young civil liberties enthusiasts toward such ends, using a free speech lawyer as a gobetween. The plaintiffs insisted that each repertoire of knowledge has to be represented evenly-for example, in curricula or textbooks-for freedom of speech to be secured. We detail the unfolding of this exemplary case in the federal courts of Boston, Massachusetts, and its consequences for knowledge about the Armenian genocide. The United States is a most appropriate setting in which to examine such a conflict in the realm of law, because it is home to one of the largest Armenian diasporas, second only to Russia, and because in the United States, compared to other Western democracies, the legal arena is most prominent in the settling of conflicts. Again, interviews and the analysis of documents provide core evidence.

Finally, chapter 9 examines the counterproductive outcome of denialism in the context of a (partial) human rights hegemony. Here I return to the American and French cases to show the blowback that denial caused those who engaged in it. Their attempts resulted in substantial ethnic mobilization and support by human rights organizations and state actors, who used various means at their disposal toward a solidification of genocide knowledge among the victim group. I supplement these case studies by an analysis of the public sphere, specifically news media and documentary films.

The overall model sketched here is depicted in figure 1. It leads from social interaction and interventions by knowledge entrepreneurs to a group-specific sedimentation of knowledge, attempts to solidify such knowledge against 




FIGURE 1. Epistemic circle: Formation of genocide knowledge in a multicausal process.

competing views through rituals, and conflictual engagement with challengers in the fields of law and politics. All of this unfolds in specific nation-states with their particular institutions, as well as in a global realm in which human rights principles have gained a hegemonic status. Once sedimented and secured, knowledge repertoires then feed back to the micro-level through socialization processes. The epistemic circle, or circle of knowledge, closes.

In line with a broad constructionist approach, I am not concerned with knowledge produced by specialists, but with knowledge generated in the context of practical action, in everyday life and in fields of law and politics (in line with Swidler and Arditi 1994). The study of knowledge about the past, in the form of collective memory (Olick 1999; Schwartz and Schuman 2005) or cultural trauma (Alexander et al. 2004), aligns well with such constructionism. Note, however, that knowledge produced by specialists (Camic and Gross 2001; Collins 2000) may, at times, and possibly with substantial lags, feed into an understanding of reality in everyday life. The common view of our world as a globe circling around the sun is one example from the natural sciences.

To avoid any misunderstandings, I must state that this book is not an attempt to answer the question of truth-even though I have my own understanding of the history of mass violence against the Ottoman Armenians. My understanding is consistent with overwhelming historical scholarship and expressed in the language I use. Throughout, I refer to this catastrophic chapter of mass violence as the Armenian genocide. Yet, working in a sociology of knowledge frame, I take 
seriously the knowledge repertoires on all sides. Those who endure denialist provocations, especially, should have an interest in understanding the knowledge that so radically clashes with their own and the conditions that generate, solidify, and diffuse that knowledge.

This book is also not a sociology of genocide; I do not seek to explain causes of genocide. Yet I am interested in the contending parties' knowledge about the conditions of genocide, because they are part of genocide knowledge. Importantly, the outcome of struggles over genocide knowledge may affect the likelihood of future genocides.

Finally, this book is not an exhaustive evaluation of literature, neither in the sociology of knowledge nor on the history or sociology of (the Armenian) genocide. It is instead an effort at bringing core elements of these two distinct bodies of literature into a conversation.

\section{FOR WHOM I WROTE THIS BOOK-CHANCES \\ AND RISKS}

I wrote this book simultaneously for those interested in the sociology of knowledge and collective memory; for those concerned with the denial and recognition of genocide and other forms of mass violence, specifically of the Armenian genocide; and finally for those interested broadly in the buildup of contradictory repertoires of knowledge and the dynamics that unfold between them.

For readers with an interest in the sociology of knowledge, my project confirms the applicability of this sociological specialty to the social and cultural processing of mass violence. By drawing on a wealth of classical and contemporary traditions, I simultaneously show the value added by each approach and potential gains from its application to the difficult theme of genocide. For those concerned with collective memory, I suggest that opening up the broader toolbox of the sociology of knowledge provides new perspectives.

While the promises are substantial, by addressing genocide through a sociology of knowledge perspective, I also enter into dangerous terrain. Seeking to avoid misinterpretations, I did not adapt Berger and Luckmann's famous title, The Social Construction of Reality, into The Social Construction of Genocidal Reality. As a sociological constructionist, I recognize that our understanding of social reality and history is always culturally processed. Yet, as a philosophical realist (Ferraris 2014), I know that the pain, suffering, humiliation, and death of those who fell victim to genocides and other forms of mass violence are all too real. While the term genocide is a judicial construction, and while our knowledge about genocides is the result of cultural processing, there is most certainly a real referent to the phenomena the term genocide covers. 
I am simultaneously writing for readers who are concerned with recognition and denial of genocides and other forms of mass violence generally, and of the Armenian genocide in particular. I hope that helping these readers look at familiar themes through a sociology of knowledge lens will supply them with fresh, and maybe surprising, insights. I also hope to answer some questions that almost certainly plague these readers: How can "the other side" insist on denial even in the face of massive evidence? What kinds of strategies do its protagonists use to spread denial? What are their chances at succeeding? How do members of victim groups respond? Which of their responses are helpful in enhancing recognition, and which are counterproductive?

Finally, and more broadly, I wrote this book for those who are desperate to understand the coexistence of, and interaction between, radically opposed repertoires of knowledge; their emergence, their solidification, and their confrontations; and, closely related, the denial of well-established facts, especially by populist leaders and their followers. Such confrontation is increasingly common, and it is destabilizing. This book thus speaks to all concerned with the dynamics that today contribute to a destabilization of our social and political world.

\section{GENOCIDE AGAINST THE OTTOMAN ARMENIANS IN CONTEXT}

Again, this book is not about the history of the Armenian genocide. It is instead a sociology of genocide knowledge, examining how different collectivities know and tell this history. Yet some basic historical information is in order. I thus conclude this introduction with a nutshell summary of the prehistory, history, and post-history of the violence, to which subsequent chapters add detail. I here focus on basic information on which historians have reached an overwhelming consensus, even if disagreements on details and specific aspects remain. These historians, supplemented by historical-comparative sociologists, include Fikret Adanir, Boris Adjemian, Taner Akçam, Donald Bloxham, Hamit Borzaslan, Bedross Der Matossian, Vincent Duclert, Fatma Müge Göçek, Richard Hovannisian, Raymond Kévorkian, Hans-Lukas Kieser, Bernard Lewis (despite his rejection of the genocide label), Claire Mouradian, Ronald Grigor Suny, Yves Ternon, and Uğur Ümit Üngör. ${ }^{2}$

This is not the place, of course, to tell the more than three-thousand-year history of the Armenian people. Historians trace this people's migration from the Caucasus region into Asia Minor, its early Christianization in the first century CE, its establishment of a territorial state with shifting boundaries, most expansive in the first century, and the invention of its own alphabet in the fifth century. Nor is this the place to tell the history of the Ottoman Empire, which arose in the fourteenth century. At the time of its greatest expansion, from the 
sixteenth through the nineteenth centuries, the empire controlled much of the Middle East and the Arab world, the North African coastal regions, and Southeastern Europe. By the sixteenth century, the empire had also incorporated the Armenian people.

The decline of the Ottoman Empire, conflicts among its neighbors, and the rise of ethno-nationalism became crucial preconditions for the Armenian genocide. In 1804-13 and 1826-28, two Russo-Persian wars resulted in the incorporation of Eastern Armenia (Yerevan and Karabakh) into the Russian Empire. Most territories with predominantly Armenian populations, however, remained under Ottoman rule. Armenians, and other minorities, now enjoyed limited equality within the millet system of relatively autonomous self-administration. Yet they suffered substantially higher tax burdens and were prohibited from bearing arms. In addition, military defeats suffered by the Ottoman Empire resulted in the scapegoating of minorities and increasing repression, culminating in the mass killings of more than two hundred thousand Armenians in 1894-96 under Sultan Abdülhamid II (the Hamidian massacres). Simultaneously, Armenian movements formed and radicalized, including the Dashnaks, a nationalist and socialist political party founded in 1890 in Tiflis (Georgia).

The Young Turk revolution of 1908 and the overthrow of the sultan brought hope to the country's minorities, but that hope was short lived. For Armenians it ended in 1909 with a massacre of thousands in the city of Adana. For the postrevolutionary Ottoman Empire, hope was crushed by military defeats during the Balkan Wars of 1912 and 1913. These wars resulted in the loss of the most economically developed parts of the empire, the forced resettlement of hundreds of thousands of ethnic Turks from the Balkans into Anatolia, and-in reaction-a massive campaign of Turkification of space, people, and the economy.

The catastrophe suffered by the Ottoman Armenians unfolded soon thereafter in the context of World War I (1914-18), during which the Ottoman Empire was allied with Austria-Hungary and the German Empire. The Young Turk government now defined the Armenian minority, small and radicalized segments of which had risen up in opposition, as an internal tumor. It set up the Special Organization, a militia force dedicated to the repression of internal opposition and minority groups. The first deportations of Armenians began in March 1915. On April 24, 1915, the regime rounded up, deported, and killed hundreds of Armenian intellectuals, silencing their voices in anticipation of an outcry that would have accompanied the following events. These events included the killing of tens of thousands of Armenian men and the deportation, by train and by foot, of hundreds of thousands, mostly women and children, to concentration camps in the deserts of Syria and Mesopotamia. Thousands perished from exhaustion and starvation along the way. By March 1916, half a million subsisted in camps, where many died from starvation. Most fell victim to mass liquidations. Map 1 represents crucial elements of this process. 


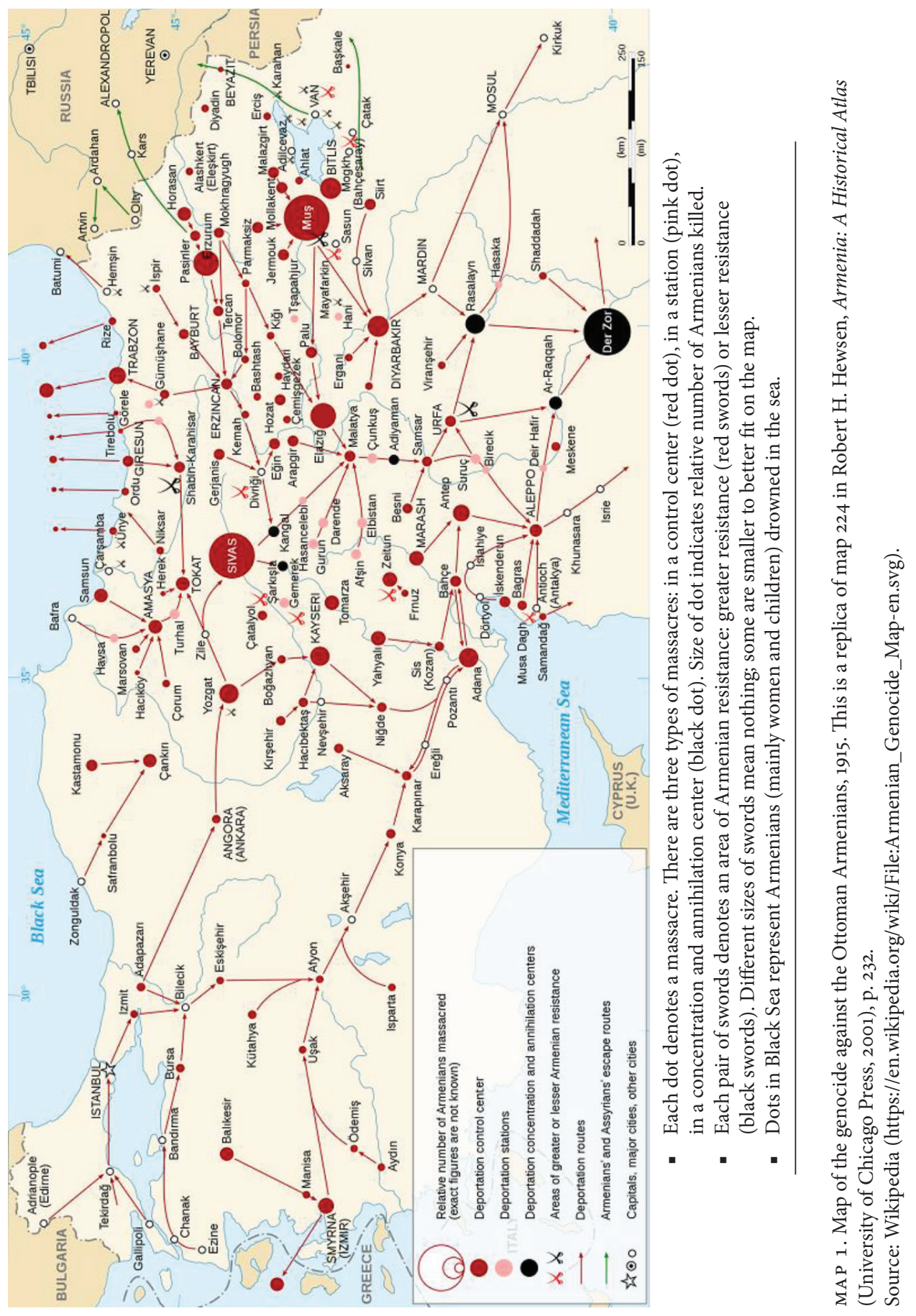


While historiography largely agrees on the basic facts, differences pertain to the specific conditions and the pattern of the unfolding genocide. Some scholars place greater emphasis on religion and continuity of violence or nationalism, while others highlight demographic engineering; further, while some focus on one moment of decision making, others see a cumulative policy radicalization, stressing the contingency of the unfolding events (see overview by Der Matossian 2015).

Events shortly before and after the end of World War I further determined the fate of the Armenians in the postwar order. Initially, the Russian Revolution of 1917 provided opportunities for nationalist Armenians to create an independent Armenia (May 1918). Hopes were further elevated by the Treaty of Sèvres, signed on August 10, 1920, the outcome of negotiations between the victorious powers of World War I and the Ottoman Empire. This treaty promised vast territories to the new Armenian state, reaching far into today's Turkey.

Almost simultaneously, however, the Turkish National Movement under the leadership of Mustafa Kemal (Atatürk) established the Turkish Republic, overthrew the sultan, moved the capital from Constantinople to Ankara, and engaged in a war of independence against the occupying powers. The new Turkish government did not recognize the Treaty of Sèvres. Working to neutralize some of the losses resulting from defeat in World War I, its leaders coordinated with the new Soviet Union an attack on Armenia, with Soviet troops invading from the north and Turkish troops from the south. The northern part of Armenia was incorporated into the Soviet Union, and major territories of the short-lived Armenian state were returned to Turkey, including those eastern sections where Armenians had been the dominant population group before 1915. The year 1920 thus marked the end of the short-lived first Armenian republic. The Soviet authorities eventually merged what remained of Armenia with Georgia and Azerbaijan into the Transcaucasian Socialist Republic (1922-36), until they eventually allowed for the establishment of a separate Armenian Soviet Republic (1936). These moves contributed to a replacement of the Treaty of Sèvres by the Treaty of Lausanne (1923), which, for the time being, ended all Armenian hopes for an independent country.

Meanwhile, the new Turkish Republic, under the leadership of Atatürk, stabilized during the 1920s and 1930s. It remained neutral during World War II, and in the war's aftermath joined the United Nations (1945) and the North Atlantic Treaty Organization (1952). Civilian governments took turns with military rule after several successful coups. In the 1990 s and early 2000s, Turkey negotiated, albeit unsuccessfully, for membership in the European Union. Secular since Atatürk, the republic displayed a more religious orientation beginning in the early 2000 , under the populist and increasingly authoritarian rule of prime minister, and then president, Recep Tayyip Erdoğan and his Justice and Development Party (AKP). Throughout, Turkey sought to eradicate remnants of Armenian culture and the memory of Armenian contributions to the history of the Ottoman Empire. 
The former Soviet Republic of Armenia, for its part, declared independence from the Russian Federation in 1994. The relatively poor country, with a population of some three million people and its capital city of Yerevan, is in close exchange with a much larger diaspora of an estimated eight million ethnic Armenians, mostly in France, the United States, and Russia.

What, then, do Armenians, Turks, and world society know about the mass violence against the Armenians during World War I? How did their knowledge change over time and under what conditions? These questions are the subject of the following sociology of knowledge explorations. 